\title{
Podmiotowość i wspólnotowość w amerykańskiej koncepcji settlement i polskich programach integracji migrantów w społecznościach lokalnych
}

\begin{abstract}
STRESZCZENIE
Współczesne dyskusje o problemach państw europejskich przyjmujących rzesze migrantów stanowią wiodące wątki namysłu nad humanitarnymi rozwiązaniami problemu masowego napływu obywateli różnych narodowości i kultur do Europy, a także współczesnego rozumienia idei wielokulturowości, tolerancji oraz przestrzegania praw człowieka. Celem artykułu jest ukazanie pomijanego dotąd wątku obywatelskiego działania w społecznościach lokalnych na rzecz integracji i inkluzji migrantów i azylantów. Przykład XIX projektu Hull House z Chicago (USA) ukazuje, jak próbowano ten problem rozwiązywać lokalnymi siłami społecznymi w czasach, gdy migrantami byli Europejczycy. Autorki zadają w tym kontekście pytanie, czy i w jakim stopniu w czasach współczesnych rola obywateli jest i powinna być bardziej znacząca w debatach polityki społecznej i międzynarodowych dyskusjach międzypaństwowych. Ukazują szereg współczesnych inicjatyw lokalnych, będących odpowiedzią zwykłych mieszkańców na to, jak widzą możliwości i realizacje działań przyjmujących i włączających nowych przybyszów do społeczeństwa.
\end{abstract}

1 Agnieszka Naumiuk, Wydział Pedagogiczny, Uniwersytet Warszawski, Polska, e-mail: agnieszka.naumiuk@uw.edu.pl, ORCID ID: https://orcid.org/0000-0001-5390-4263.

2 Marta Pietrusińska, Wydział Pedagogiczny, Uniwersytet Warszawski, Polska, e-mail: mpietrusinska@uw.edu.pl, ORCID ID: https://orcid.org/0000-0002-1248-6816. 


\title{
Słowa kluczowe:
}

obywatelstwo, migracja, settlement, zasoby środowiska lokalnego, Jane Addams

\begin{abstract}
Contemporary discussions about the European countries' problems of hosting masses of migrants are the leading themes of various cultural and educational debates, in particular, around the reflection on humanitarian solutions to the problem of mass influx of foreigners coming to Europe. The question is raised on processes of adaptation of citizens with different nationalities and cultures, as well as on current understandings of the idea of multiculturalism, tolerance and respect for human rights. The aim of the article is to show the topic, still nor studied to greater extend, on how local communities engage in the integration and inclusion processes towards migrants and asylum seekers. The 19th example of the Hull House project from Chicago, USA shows how the problem was addressed by local social networks at a time when Europeans were migrating. The authors ask in this context, whether and to what extent, in modern times, the active role of local communities and their citizens is and/or should be more significant in actions and debates on national and international social policies towards migrants. A number of contemporary local initiatives in Poland are shown as the examples of the ordinary residents response to the possibilities and implementations of local actions aimed at integrating and engaging newcomers in the society.
\end{abstract}

\section{Keywords:}

citizenship, migration, settlement, local community resources, Jane Addams

\section{WPROWADZENIE}

Doświadczenia poprzednich stuleci i historie migracji światowych pokazują, że procesy przemieszczania się dużych grup ludności nie są ani zjawiskiem nowym, ani nieznanym. Za każdym razem, gdy do nich dochodzi wskutek różnorodnych czynników społecznych, politycznych, kulturowych, ekonomicznych czy w wyniku kataklizmów naturalnych, wywołują jednak gorące dyskusje na temat tego, jak państwa, społeczeństwa, grupy oraz jednostki mają się wobec tego zjawiska zachować: jak przyjmować, integrować się i akceptować różnorodność. Współcześnie dysponujemy znaczną wiedzą o wielu metodach pracy z migrantami. Istnieją także powołane do tego wyspecjalizowane instytucje. W XXI wieku obserwujemy 
jednak nie tylko kolejne wzmożone migracyjne fale, zwłaszcza do Europy, ale i próby podejmowania strategii i rozwiązań globalnych. W poniższym artykule pragniemy ukazać na przykładzie amerykańskiej koncepcji settlement (cieszącej się wielką popularnością w poprzednim stuleciu) oraz na podstawie współczesnych programów pomocowych w Polsce podejmowanych na rzecz migrantów, że odgórne rozwiązania bez powiązania z bliską ludziom praktyką uczenia się inności drugiego człowieka w codziennych sytuacjach, w lokalnym wymiarze, są w edukacji ważnym zagadnieniem kształtowania postaw wobec „obcych”.

\section{PRZYKŁAD SETTLEMENTU HULL HOUSE JAKO PROJEKTU PREWENCYJNEGO WOBEC PROBLEMÓW POGŁĘBIAJĄCYCH SIĘ ENKLAW BIEDY ZWIAZZANYCH Z MASOWYMI MIGRACJAMI}

Modele amerykańskich settlementów były inspirowane wcześniejszymi rozwiązaniami europejskimi (przede wszystkim angielskim Toynbee Hall w Londynie), ale także stały się na wiele lat wzorcem dla innych inicjatyw międzynarodowych opartych o podobny styl działania ${ }^{3}$. Przełom XIX i XX wieku można nazwać stuleciem koncepcji settlement nie tylko ze względu na pozytywne rezultaty i upowszechnianie się tej inicjatywy, ale przede wszystkim z uwagi na szereg czynników, które umożliwiły realizację tej idei w praktyce. Być może angielski model pomocy ubogim pozostałby lokalnym rozwiązaniem, gdyby nie został zaadoptowany do pracy z grupami osób, dla których bieda powiązana była z wyzwaniami adaptacji w kraju przyjmującym ich jako migrantów. Bodźcem rozwoju ruchu settlement w USA stały się bowiem masowe migracje, a konsekwencją brak zaspokojenie potrzeb migrantów oraz brak wypracowanych wzorców przyjmowania tak wielkich rzesz osób przez kształtujące się społeczeństwo. Potrzebna była zwłaszcza integracja słabo przygotowanych do pełnego uczestnictwa migrantów, który wybrali Amerykę za swoją drugą ojczyznę. Istotą sukcesu okazała się siła oddolnych działań obywateli, którzy z pasją i niezwykłą energią realizowali marzenie o lepszym społeczeństwie (Barbuto, 1999).

${ }^{3}$ Ruch settlementów był reformatorskim ruchem społecznym końca XIX wieku, szczególnie popularnym w Anglii i w USA. Jego celem było zbliżenie różnych warstw społecznych, zwłaszcza w dzielnicach biedy dużych miast. Polegał na tworzeniu miejsc, w których przedstawiciele klasy średniej mogli pomagać i dzielić się swoją wiedzą z osobami ubogimi. 


\subsection{KONCEPCJA INKLUZJI DŁUGOFALOWEJ I TOWARZYSZENIA IMIGRANTOM W CODZIENNYM ŻYCIU}

Początek XIX wieku w USA to okres znaczącego rozwoju przemysłu oraz przemian industrialnych w miastach amerykańskich. Spowodowany był on między innymi napływem masowej migracji z Europy, Azji i Ameryki Południowej do Ameryki Północnej, zwłaszcza do Stanów Zjednoczonych postrzeganych jako miejsce nieograniczonych możliwości oraz przystanek do dobrobytu i wolności. Zwłaszcza w Europie, przez którą przetaczało się wiele konfliktów zbrojnych, a uciski ekonomiczne, społeczne i polityczne stawały się dla wielu nie do zniesienia - wizja lepszego życia i możliwości uczestniczenia w kształtowaniu nowego społeczeństwa inspirowała do podejmowania ryzyka podróży i trudności osiedleńczych towarzyszących początkom życia w nowym kraju. Napływ migrantów wpisany był w ideę amerykańskiego społeczeństwa wielokulturowego jednak w XIX wiek ujawnił, iż wszelkie masowe zmiany rodzą szereg problemów i wyzwań, w tym brak możliwości społecznej kontroli i realizacji założeń zrównoważonego rozwoju. Szczególnie miasta Wschodniego Wybrzeża USA silnie odczuwały zmiany społeczne spowodowane masową imigracją. Z jednej strony tania siła robocza była potrzebna z uwagi na ogromną dynamikę rozwoju miast i przemysłu amerykańskiego, z drugiej strony, bezrobocie lub niskie wynagrodzenia wymuszały życie w warunkach urągających higienie i bezpieczeństwu. Złe warunki zaś stanowiły kolejne zagrożenia: zdrowotne, związane z rosnącą przestępczością i patologiami zachowań. Brak opieki i wsparcia rządowego oraz władz lokalnych skutkował pogłębianiem się sytuacji kryzysowych, zwłaszcza w dzielnicach, gdzie zamieszkiwali biedniejsi migranci. Z kolei brak zainteresowania, wręcz niechęć mieszkańców bogatszych dzielnic, powodował izolację i zwiększał separację społeczną na tle ekonomicznym, etnicznym i kulturowym. Wysiłkiem wielu osób, grup i instytucji starano się tę sytuację zmieniać. Masowo, wraz z towarzyszącą migrantom biedą, pojawiały się działania filantropijne i dobroczynne, wpisujące się w kulturę samoorganizacji, która pozwoliła narodowi amerykańskiemu na przetrwanie trudnych początków kształtowania tożsamości i ekonomicznego oraz społecznego rozwoju (Bryan, McCree, Davis, 1990; Knight, 2005, 2010). Miastami szczególnie odczuwającymi presję masowych migracji były m.in. Nowy Jork, Boston czy Chicago, które stały się centrami absorpcji i transferu fal migracyjnych na inne obszary Stanów Zjednoczonych.

Jedną z inicjatorek ruchu settlement w Stanach Zjednoczonych była Jane Addams (Knight, 2005), której inicjatywa w Chicago (1889-1965) okazała się wielkim, długofalowym sukcesem, a z czasem także modelowym rozwiąza- 
niem dla tego typu inicjatyw w USA i inspiracją dla podobnych działań w innych krajach. Mimo, iż w koncepcji osiedlania się w dzielnicach biedy i pracy z mieszkańcami, nie była pionierką (zainspirowała się działalnością placówki założonej przez Henriettę i Samuela Barnetów w Londynie), a w samej realizacji pomysłu nie była osamotniona (za współtwórczynię Hull House uważana jest także jej przyjaciółka Eleen Gates Star), to w szczególny sposób właśnie ta inicjatywa zapisała się w historii dziejów pomocy ubogim i pracy integracyjnej z imigrantami, we współpracy ze środowiskiem lokalnym. Za ideą Hull House stała bowiem, rozwijała się i doskonaliła koncepcja pracy środowiskowej (Naumiuk, 2016, 2017) w duchu szacunku dla człowieka z jednoczesnym moralnym imperatywem konieczności zmiany warunków, w których żyje, a drogą, która z założenia powinna do tego prowadzić, miał być społeczny, oddolny ruch światłych Amerykanów przebudowujących w praktyce system wykazujący poważne braki w realizacji konstytucyjnej idei sprawiedliwości społecznej i równości wszystkich obywateli (tzw. progresywizm społeczny). Amerykańska demokracja leżąca u podstaw ideologicznych koncepcji praktyki została, na drodze swoistego eksperymentu społecznego, przetestowana. Odnosiło się to zarówno do inicjatyw realizowanych w Hull House, jak i postaw moralnych oraz idei społecznych realizatorów tego projektu, ale także zmian istniejących przepisów. Za jednym z najdłużej trwających projektów obywatelskich stała prawdopodobnie nie tylko charyzma i zdolności przywódcze twórczyni Hull House, ale i zbiorowe, oparte na pogłębionej refleksji nastawienie wszystkich osób zaangażowanych w codzienne trwanie, a później kontynuację praktyki pomocowej (Knight, 2005, 2010; Opdycke, 2012). Charakterystykę tego podejścia najlepiej oddaje koncepcja Jacka Mizerowa - transformatywnego uczenia się - jako stylu autoedukacji poprzez działanie i relacje, zmieniające i utrwalające koncepcje, wizje i wyobrażenia o czymś, na myślenie i działanie bardziej otwarte, respektujące różne punkty widzenia, wprowadzającego inkluzyjny styl pracy zbliżający do bardziej świadomych działań (Mezirow, 2003, s. 58-59). Droga przebytej refleksji zawarta jest w publikacji Addams pt. Twenty Years of Hull House (Addams, 1910), w której opisuje trudne początki, popełniane błędy i podejmowane działania. Idea pomocy ubogim nie była nowa, jednak koncepcja settlement różniła się od paternalistycznych koncepcji charytatywności różnorodnych inicjatyw dobroczynnych, a nawet bardziej zorganizowanych, lecz opartych na doraźnej pomocy COSów (Stowarzyszeń Organizacji Dobroczynnych), choć, jak przyznaje sama Addams, jej własna naiwność w początkowym podejściu do problemów ubogich rodzin została także wystawiona na próbę. Perspektywa dobrze sytuowanej feministki uważającej się za rodowitą amerykankę stawiała pod znakiem zapytania zarówno 
pomysł promowania kultury Europy, Azji czy Meksyku w oderwaniu od zrozumienia trudnych warunków bytowych migrantów, jak i sam pomysł zakupu domu w środku chicagowskiego getta i rozwijania poprzez to konkretne miejsce idei promieniującej centrum kultury i integracji. Pomysł ten spotkał się zatem początkowo z dużą rezerwą zarówno samych migrantów, jak i innych mieszkańców dzielnicy. Droga do wypracowania relacji oraz odpowiednich projektów, które stanowiłyby fundamenty długofalowego działania, stała się drogą nieustającej wewnętrznej przemiany jednostek i grup - po stronie osób pomagających - oraz tych, którym oferowano pomoc. Pełna była ona nieporozumień, negatywnych aspektów kulturowego szoku i agresji w stosunku do „obcych” po obu stronach. Z uwagi na determinację i decyzję o własnym zakorzenieniu zbudowaniu otwartego miejsca na gości, sąsiadów, którzy nie są „inni” czy „gorsi” lecz „swoi” - różnorodni i interesujący, mimo wyzwań warunków życia w dzielnicy biedy, mimo potencjalnego innego wyboru drogi życiowej, udało się uniknąć niepowodzenia tej inicjatywy. Stała się wręcz we współczesnym czasie jednym z modeli działań lokalnych.

W koncepcji Hull House leżało założenie, że będzie to swoiste centrum społeczno-edukacyjne, ale oparte na zasadach środowiskowych - długofalowego, ewolucyjnego rozwoju i stopniowej akceptacji jego istnienia i założeń przez mieszkańców. Stąd pomysł, zaczerpnięty z Anglii, by wolontariusze i pracownicy Hull House stali się „,rezydentami” (mieszkali i działali od kilku tygodni, do kilku miesięcy a nawet, jak niektórzy zdecydowali - wielu lat). Koncepcja innego niż jednorazowe działania, wynikała z progresywistycznych ideałów, które miały być wprowadzane w rzeczywistości poprzez przykład własnego życia, czasem wręcz jego poświęcania na rzecz realizacji zmiany społecznej (Eberhard, 1995). W settlemencie Hull House zainicjowano wiele programów dla ubogich migrantów. Wspierano także wiele ich własnych inicjatyw - z czasem oddając gros tego typu działań samym imigrantom. Szacowano, iż około 2000 osób tygodniowo uczestniczyło w różnych działaniach edukacyjnych, sportowych i artystycznych. Szczególną wagę przywiązywano do roli sztuki w integrowaniu różnych grup społecznych i etnicznych - wzajemne uczenie się od siebie i formułę dialogu międzykulturowego, popularyzowanego współcześnie w działaniach animacyjnych. Sztuka pełniła także rolę wzmacniania talentów i pasji, odkrywania silnych stron człowieka, ale także traktowano ją jako formułę relaksu, wypoczynku i zabawy. Formy wyrazu artystycznego były przeróżne: począwszy od warsztatów plastycznych i muzycznych dla dzieci, poprzez męskie, damskie i mieszane chóry i zespoły muzyczne, zespoły taneczne ludowe i historyczne, spotkania poetyckie, zorganizowane grupy czytelnicze i dyskusyjne, wystawianie przedstawień teatralnych, aż po wystawy malarskie, spotkania z artystami. Pojawiały się coraz to nowe 
pracownie: garncarskie, szwalnicze, nauki gotowania, nauki pisania poematów i dramatów, śpiewu, gry na instrumentach i wiele innych.

Poza wymienionymi działaniami artystycznymi stworzona została pierwsza w Chicago trupa teatralna występująca z europejskimi sztukami dramatycznymi, pierwsza w USA liga futbolowa kobiet, pierwsza profesjonalna orkiestra złożona z muzyków niewykształconych w USA. Wiele odmian sportu, takich jak: boks, szermierka piłka nożna, gimnastyka, koszykówka, siatkówka itp., było nie tylko formami uprawiania sportu i rekreacji. Poza pomocą w zachowaniu sprawności fizycznej oraz odreagowaniu trosk i kłopotów miały służyć też wzmacnianiu kondycji potrzebnej w wykonywaniu niekiedy bardzo ciężkiej pracy fizycznej oraz miały kształtować nawyki zdrowotne i postawy ducha walki, umiejętność rywalizacji oraz gry (i pracy) zespołowej. Dzięki tym działaniom imigranci i mieszkańcy dzielnicy mieli uczyć się wiary we własne siły i roli współpracy - dzielenia wspólnego losu i chęci jego zmiany na lepsze. Uczestnicząc w różnorodnych programach Hull House, uczyli się przy tym zasad etycznego postępowania, adaptacji do kultury, którą wybrali. Z ich inicjatywy z czasem ruszyły także kursy zawodowe i dokształcające: szycia, gotowania, florystyki, mechaniki samochodowej czy elektryczne, ale także księgowości, opiekuńcze. Później zaczęto organizować także kursy wieczorowe pozwalające uzyskać wykształcenie i umożliwiak=jące przygotowywanie się do studiów wyższych, a także zorganizowano opiekę i edukację dzieci w postaci żłobków, przedszkoli i szkół (Deegan, 2002; Glowacki, Hendry, 2004; Knight, 2010). Organizowane były wykłady otwarte we współpracy z Uniwersytetem Chicagowskim, z którym także nawiązano długofalową współpracę badawczą i dydaktyczną. Studenci odbywający praktyki w dzielnicy objętej opieką Hull House, zdobywali cenne doświadczenie w pracy nad integracją społeczną: uczestniczyli nie tylko w działaniach animacyjnych lub prowadzili kursy, opiekowali się dziećmi, ale także odwiedzali domy i diagnozowali potrzeby mieszkańców, wspierali w pisaniu pism procesowych i przygotowywaniu innej dokumentacji formalnej.

Tylko dzięki długofalowemu działaniu środowiskowemu mogli uczyć się, jak przez lata zmieniała się sytuacja mieszkańców, jak należy dostosowywać się do kolejnych wyzwań, a także jak odpowiadać na ich wzrastającą świadomość społeczną i edukacyjną oraz obserwować, jak zmiany społeczno-ekonomiczne oraz prawne - zarówno lokalne jak i ogólnokrajowe - wpływają na procesy społeczne. To swoiste pole doświadczalne i uczestnictwo w reformach społecznych stanowiło jednocześnie wielkie zobowiązanie wobec organizatorów, którzy na co dzień musieli świadczyć o sensowności i celowości podejmowanych działań, stawiać czoła niejednokrotnie trudnym sytuacjom, w których ani oni, ani ich podopieczni 
nie byli anonimowi - nie mogli ukryć się w rolach systemu pomocowego czy prawnego. Byli mieszkającymi obok siebie, choćby tymczasowo, sąsiadami. Długofalowość działań miała swoje konsekwencje: regularne działania zapewniały większą trwałość edukacji realizowanej codziennie, małymi krokami, z głębszym zrozumieniem trudności, jakie towarzyszą człowiekowi, który musi nagle zmienić całe dotychczasowe życie, nawyki, kulturę - wykorzenia się w celu ponownego zakorzenienia.

\subsection{MODEL ODDOLNYCH DZIAŁAŃ OBYWATELSKICH I WZORZEC ELASTYCZNYCH METOD PRACY ZE SPOŁECZNOŚCIĄ LOKALNĄ NA RZECZ INTEGRACJI.}

Rezydenci Hull House pochodzący z wielu krajów europejskich: Niemiec, Francji, Włoch, Grecji, Bułgarii, Szwecji, Norwegii, Anglii, Irlandii, Szkocji, Rosji, Holandii, Portugalii, Hiszpanii, ale także z Chin i Meksyku, doświadczali życia w biedzie, niepewności, ciągłej zmianie prawa, przy jednoczesnym podejmowaniu wysiłków, by zmieniać tę sytuację, niejednokrotnie w konflikcie z innymi grupami etnicznymi i narodowościowych. Addams, zdając sobie sprawę, że pobyt i praca z mieszkańcami dzielnicy jest trudna, ale i dobrowolna, ustaliła demokratyczne reguły organizacji pracy settlementu. Powołała stowarzyszenie, a organem nadzorczym ustanowiła walne zebranie członków stowarzyszenia. Nie poprzestając na tworzeniu oddolnych mechanizmów samoregulacyjnych i autoedukacyjnych cyklicznie, w głównym budynku kompleksu, organizowano zgromadzenie rezydentów, na którym omawiano bieżącą pracę i plany na przyszłość. W wielu wypadkach to demokratyczne gremium wyrażało zdanie odmienne od Addams, jednak być może z tego powodu tak długie i pełne sukcesów okazało się to przedsięwzięcie. W literaturze poświęconej Addams przypisuje się jej wiele zasług - co niewątpliwie jest prawdą i świadczy o jej talentach organizacyjnych, oratorskich i budowania relacji społecznych, ale także o tytanicznej pracy, poświęceniu i osobistemu zaangażowaniu setek innych działaczy społecznych. Założenie, iż Hull House opiera się na inicjatywach oddolnych, było wtórne, jednak silnie zakorzeniło się w charakterystyce projektu społecznego. Jak sama Addams przyznawała, musiała pozbyć się utopijnego stylu swoich pierwotnych zamierzeń. Bycie z człowiekiem, towarzyszenie mu, inspirowanie i animowanie sytuacji po to, by z czasem sam odkrył swój potencjał i inicjował to, co jemu i innym jest przydatne, stanowiło o walorach rozrastania się idei w sposób naturalny, bez zbędnych kontroli i pilnowania sztucznego „wzorca”. W założeniu settlementu każdy miał się czuć pełnoprawnym członkiem wspólnoty sąsiedzkiej. Trudno po latach oceniać, na ile te założenia były w takiej formule realizowane (krytycy podkreślają 
np. nierówność ról wykształconej klasy średniej i ubogich imigrantów, jednak opisy stylu pracy wykazywały na istotną wartość zarówno samej demokracji jako fundamentu amerykańskiego społeczeństwa, jak też założenia pełnego obywatelstwa nowych przybyszów - ich praw i obowiązków, zrozumienia trudnej sytuacji ale i podpowiedzi, jak tę sytuacje powinni przełamywać. Edukacja obywatelska w rozumieniu Addams odbywała się na wielu poziomach: praktycznym, życia codziennego i aspiracji edukacyjnych - osiągania sukcesu zawodowego i społecznego przez dorosłych, dzieci oraz młodzież. Podejście to wychodziło daleko poza obszar jednej tylko dzielnicy Chicago - inspirowała i zmuszała do refleksji nad prawem, systemami i wartościami demokracji kolejne pokolenia aktywistów, mieszkańców Chicago i kolejne pokolenia migrantów (Elshtain, 2002; Fradin, Fradin, 2006; Opdycke, 2012).

Dla pedagoga oczywiste jest spojrzenie na aspekty pedagogiczne tej idei, jednak z uwagi na środowiskowy cel i wymiar pracy z grupami zagrożonymi marginalizacją jest to kontekst ujmujący przede wszystkim społeczno-kulturowe i edukacyjne przesłanki jego założeń, treści i skutków. Z tego m.in. powodu współczesne koncepcje i realizacje idei settlementów w Europie i na świecie, czerpiące w dużym stopniu z dorobku chicagowskich doświadczeń, coraz powszechniej zostają dostrzegane i dyskutowane w kontekście potencjału środowiska lokalnego i jego roli w przemianie kultury życia codziennego enklaw migracyjnej biedy. Tym bardziej jest to ważne zagadnienie, że debata o współczesności działań lokalnych na rzecz imigrantów i roli społeczności w jej realizacji, jak wskażą przykłady współczesnych rozwiązań przedstawione w dalszej części artykułu, stanowią o skutkach praktycznych w postaci podejmowanych strategii i rozwiązań na temat planowania, organizowania i realizowania działań integracyjnych w sytuacji migrowania i przyjmowania dużych grup ludności innych kultur.

\section{WSPÓŁCZESNE POLSKIE INICJATYWY PRACY Z MIGRANTAMI Z WYKORZYSTANIEM ZASOBÓW ŚRODOWISKA LOKALNEGO}

Praca środowiskowa w imigranckich enklawach biedy, którą zapoczątkowała Addams w XIX wieku może stanowić nieustające inspiracje dla osób współcześnie pracujących z migrantami. Chociaż warunki, w których działała Addams, znacząco różnią się od tych, w których pracują polscy aktywiści, animatorzy i pedagodzy społeczni, głównie jeśli chodzi o intensywność migracji i jej charakter, to pewne wyzwania z nimi związane oraz wartości leżące u podstaw ich rozwiązywania pozostają takie same. W tej części artykułu, odwołując się do idei i narzędzi pracy 
z migrantami w XIX wiecznym Chicago, pokazujemy użyteczność pracy środowiskowej i angażowania społeczności lokalnych w proces integracji i inkluzji migrantów w oparciu o trzy kluczowe wartości: podmiotowość; lokalność; wspólnotę.

\subsection{KRAJOWE I LOKALNE KONTEKSTY INTEGRACJI MIGRANTÓW DRUGIEJ DEKADY XXI WIEKU}

Po ponad stu latach styl pracy środowiskowej i idea integracji migrantów promowane przez Jane Addams są nadal aktualne i adekwatne w obliczu wyzwań związanych ze współczesnymi migracjami, choć różnymi od tych chicagowskich. Chociaż w Polsce migracje zewnętrzne nie są zjawiskiem nowym, to w dyskursie publicznym pojawiły się jako problem społeczny dopiero w 2015 roku wraz z paniką moralną wywołaną tzw. kryzysem migracyjnym (Kubicki i in., 2017) (czyli masowym napływem uchodźców i imigrantów do Europy w 2015 roku i latach kolejnych); wojną na Ukrainie oraz znaczącymi zmianami politycznymi w samej Polsce (Rajca, 2015). W związku z powyższymi zmianami oraz wzrostem nacjonalizmu, ksenofobii, islamofobii, antysemityzmu (Kopiński, Hasen, 2016; Hall, Mikulska-Jolles, 2016; Pasamonik, 2017) na imigrantów i uchodźców, a także ich integrację, zaczęto patrzeć przez pryzmat sekurytyzacji, jak na zagrożenie dla społeczeństwa (Leszkowicz-Baczyński, 2017; Ziętek, 2017; Pietrusińska, 2018)4

Nasilona niechęć do migrantów jest w Polsce zjawiskiem dość nowym, ponieważ przez lata ani nie stanowili oni tematu debat politycznych, ani też nie pojawiali się w szerszym dyskursie publicznym, będąc spychani na jego margines 5 . Negatywne saldo migracyjne utrzymujące się przez ponad 25 lat po otwarciu granic w 1989 roku (ze strumieniami migrantów płynącymi głównie z takich krajów, jak: Ukraina, Białoruś, Rosja (w tym Czeczenia, Inguszetia, Dagestan), Wietnam, a w drugiej dekadzie lat dwutysięcznych rownież Gruzja, Chiny, Turcja czy Indie (Matyja, Siewierska-Chmaj, Pędziwiatr, 2015; Rajca, 2015)) było przyczyną

4 Jak wskazują statystyki, liczba uchodźców praktycznie się nie zmieniła, a liczba imigrantów z pobytem czasowym wzrosła ze względu na masowe migracje zarobkowe obywateli Ukrainy, zatem strach przed uchodźcami i migrantami w Polsce jest nieuzasadniony.

${ }^{5}$ Przez lata kwestią najczęściej podnoszoną przez polityków w kontekście migracji dotyczącą byli repatrianci, o których politycy mówili zwykle w kontekście pomocy Polakom na wschodzie (Rajca, 2015). W dyskursie medialnym pojawiali się sporadycznie także uchodźcy przedstawiani w sposób stereotypowy w oparciu o ,szablon smutnego, niezaradnego biedaka, który oczekuje wielkiego wsparcia ze strony państwa, przede wszystkim finansowego” (Hadzińska-Wyrobek, 2011, s. 125). 
biernej i dostosowawczej do unijnego prawa polskiej polityki migracyjnej (Łazor 2016; Kubicki i in., 2017)

W latach dwutysięcznych, szczególnie w drugiej dekadzie XXI wieku, polską politykę migracyjną określić można było za Sławomirem Łozińskim i Markiem Szonertem jako politykę „kontrolowanego otwarcia” (2016, s. 25). W tym czasie nie tylko znowelizowano Ustawę o cudzoziemcach ${ }^{6}$, ale także powoli rozwijano spójną, krajową politykę migracyjną opisaną w strategicznym dokumencie - Polityka migracyjna polski - stan obecny i postulowane działania, stworzonym przez MSWiA. Jej głównym celem było wzmocnienie polskiej gospodarki otwarcie polskiego rynku pracy pracowników cudzoziemskich. W realizację tej polityki głównie w obszarze integracji migrantów włączały się zarówno instytucje szczebla centralnego, samorządowego, jak i organizacje pozarządowe.

Rok 2015 przyniósł jednak znaczącą zmianę w narracji. Po raz pierwszy polityka migracyjna wyszła z cienia i stała się ważnym elementem debaty publicznej i wewnątrzkrajowych oraz geopolitycznych rozgrywek politycznych. Dyskurs dotyczący migrantów, a szczególnie uchodźców, stał się w konsekwencji antymigracyjny (Pietrusińska, 2018), a polityka migracyjna państwa została przede wszystkim ukierunkowana na kontestację unijnych polityk (Adamczyk, 2017), zapewnienie bezpieczeństwa poprzez zamykanie granic, zmniejszanie skali imigracji (Ziętek, 2017) oraz dążenie do asymilacji migrantów przebywających w Polsce. Łodziński i Szonert zaznaczają jednak z pewnym optymizmem, że od 2015 roku polska polityka migracyjna: „Staje się coraz bardziej »uspołeczniona«, przechodząc na poziom regionalny i lokalny” (2016, s. 32). W odpowiedzi na działania rządu uaktywniła się ich kontestacja nie tylko zinstytucjonalizowanych podmiotów (głównie samorządów lokalnych i organizacje pozarządowe), ale także zwykłych obywateli, którzy zaczęli aktywnie angażować się w oddolne inicjatywy na rzecz migrantów, takie jak: Refugees Welcome, Noise for Refugees, Chlebem i Solą, Inicjatywa Obywatelska WITAJ.

Część samorządów lokalnych, sprzeciwiając się polityce rządu, zaczęła wprowadzać własne rozwiązania z obszaru polityki migracyjnej, Przykładem może być podpisana przez prezydentów 12 polskich miast (Warszawa, Białystok, Gdańsk, Poznań, Kraków, Bydgoszcz, Katowice, Lublin, Łódź, Szczecin, Wrocław, Rzeszów ${ }^{7}$ ) Deklaracja o współdziałaniu miast unii metropolii polskich w dziedzinie

6 Nowa Ustawa o cudzoziemcach weszła w życie w 2013 roku. Kolejne znaczące zmiany dotyczące cudzoziemców wprowadzone zostały w 2018 roku.

7 Nie tylko w 12 metropoliach, których włodarze podpisali Deklarację o współdziałaniu miast unii metropolii polskich w dziedzinie migracji, ale i w mniejszych miastach np. Podkowa Leśna, Sopot, Bielsko-Biała, 
migracji, w której prezydenci zobowiązali się, wspierani przez Międzynarodową Organizację ds. Migracji (IOM) oraz Biuro Wysokiego Komisarza Organizacji Narodów Zjednoczonych ds. Uchodźców (UNHCR), do współdziałania razem $\mathrm{z}$,administracją rządową, organizacjami pozarządowymi i związkami religijnymi w zakresie tworzenia i wdrażania polskiej polityki migracyjnej, opartej na zarządzaniu bezpiecznymi migracjami” (Deklaracja..., 2017, s. 1). Efektem tego i podobnych działań na lokalną skalę jest pojawienia się z jednej strony dualnej polityki migracyjnej - prowadzonej odmiennie na poziomie centralnym i na poziomie samorządowym - a z drugiej strony wzmocnienie i podkreślenie znaczenia lokalności dla procesu integracji migrantów. Ta ostatnia zmiana, wymuszona niejako poprzez politykę rządową, otwiera przestrzeń do podejmowania przez pedagogów społecznych, animatorów, ale też zwykłych obywateli nowych działań na rzecz migrantów, w duchu demokracji obywatelskiej promowanej przez Addams.

\subsection{PRZEMIANY PARADYGMATU DZIAŁAŃ INTEGRACYJNYCH W POLSCE W KONTEKŚCIE MIGRACJI}

Aksjologiczne i praktyczne zdecentralizowanie polskiej polityki migracyjnej zbiegło się również z pewnym przewartościowaniem paradygmatu związanego z integracją uchodźców. W klasycznych teoriach integracja tożsama była z asymilacją i oznaczała „proces i stan będący wynikiem kontaktów z inną grupą etniczno-kulturową, w których rezultacie następuje zmiana zachowań członków grupy mniejszościowej i przyjęcie przez nich kultury i identyfikacji innej grupy” (Budyta-Budzyńska, 2016, s. 54). Wśród wskaźników integracji migrantów w takim jej rozumieniu można wymienić m.in.: zatrudnienie, miejsce i warunki zamieszkania, edukację, dostęp do opieki zdrowotnej, więzi wewnątrzgrupowe oparte o etniczne, narodowe lub religijne związki wśród homogenicznych grup migranckich, relacje z członkami grupy dominującej, kontakty z instytucjami społeczeństwa przyjmującego, znajomość języka i kultury nowego kraju, stabilność, poczucie bezpieczeństwa i ochrony prawnej, partycypacja i zaanagażowanie obywatelskie (Ager, Stranger, 2004). W integracji rozumianej w taki sposób podkreśla się przede wszystkim jednokierunkowość, nieasymetryczność oraz przemocowość tego procesu, w którym migrant poprzez zdobywanie nowych kompetencji musi przystosować się do życia w obcym, nowym społeczeństwie.

W Polsce integracja cudzoziemców przez lata przyjmowała właśnie taki charakter. Kursy języka polskiego, pomoc tzw. asystentów kulturowych, ewentualna pomoc prawna czy też socjalna - były to działania najczęściej podejmowane na 
rzecz cudzoziemców przez rządowe, samorządowe i pozarządowe podmioty. Co więcej, tak pojmowana integracja miała „festynowy” charakter (Diouf, Średziński, 2012). Była to integracja polegająca na urządzaniu spotkań, na których prezentują się członkowie wybranych kultur poprzez swoje potrawy narodowe, stroje, tańce, muzykę, sztukę. O tym sposobie integracji wspominała sama Addams: „Wydawało jej się, że wystarczą zajęcia z zakresu poezji, śpiewu czy sztuk pięknych przywracające godność i dumę z własnej tradycji osobom, których godność w pierwszej kolejności umniejszano z powodu ich etniczności i braku znajomości kultury kraju przyjmującego" (Naumiuk, 2016, s. 44-45). Takie działanie obecnie i w czasach Addams w dłuższej perspektywie nie są wystarczające dla pogłębionej integracji i wzmacniają tylko stereotypy dotyczące konkretnych kultur oraz stawiają migrantów w roli „egzotycznych przedmiotów” do oglądania.

Często takim działaniom współtowarzyszyło także wytwarzanie relacji zależności i dominacji poprzez rzadko uświadomione stawianie migrantów w pozycji osoby słabszej: nie znającej reguł, języka i kodu kulturowego. Addams wspominała o tej trudności i dążyła do wyjścia z relacji narzucania władzy w celu inkluzji i doprowadzenia do wprowadzania zasady integracji jako procesu wzajemnego uczenia się, na których opierała funkcjonowanie Hull House. Upodmiotowienie migrantów, nie tylko w znaczeniu wzmocnienia ich indywidualnych kompetencji, ale także budowania solidarnych wspólnot lokalnych, których są integralną i aktywną częścią, to wyzwanie, przed którym stała Addams nie tylko, ale które także jest istotne współcześnie (Sitko, 2016).

Nowy paradygmat wspierania integracji migrantów i społeczeństwa przyjmującego opiera się na założeniu, promowanym przez Unię Europejską, UNHCR czy IOM, że integracja proces to złożony i dynamiczny, dwukierunkowy, angażujący zarówno migrantów, jak i społeczeństwo przyjmujące, którego celem jest pełne i równe członkostwo cudzoziemców w społeczeństwie państwa przyjmującego (http:// uchodzcy.info). Zgodnie z tym podejściem nie tylko migranci, ale także członkowie społeczeństwa przyjmującego uczą się od siebie wzajemnie i poprzez te kontakty zwiększając swoje kompetencje międzykulturowe (prze)budowują społeczności, w których żyją. Ten paradygmat działań integracyjnych i inkluzyjnych opiera się nie tylko na założeniu, że migranci muszą posiąść minimalny poziom kompetencji potrzebnych im do funkcjonowania w nowym kraju (adaptacja), ale także, że potrzebne jest wzmacnianie relacjizmiędzy cudzoziemcami a autochtonami. Taki rodzaj facylitacji i pracy środowiskowej możliwy jest przede wszystkim w społecznościach lokalnych (Sitko, 2016; Fundacja Emic, 2016; Komisja Europejska, 2018). Odejście od postrzegania w Polsce integracji tylko jako adaptacji społeczno-kulturowej cudzoziemców zbiegło się także z wytworzeniem się dwugłosu w polskiej polityce 
migracyjnej i zaangażowaniem się samorządów w ich realizację. W tym miejscu historia zatacza poniekąd koło, gdyż podobny sposób pracy z migrantami, chociaż w innym kontekście historycznym, politycznym, społecznym czy ekonomicznym, ale oparty na upodmiotowieniu migrantów, solidarności i wspólnotowości oraz lokalności, promowany był w ramach Hull House przez Jane Addams.

\subsection{INICJATYWY INTEGRACJI I INKLUZJI MIGRANTÓW W ŚRODOWISKU LOKALNYM A KONCEPCJA SETTLEMENTÓW}

Praca z dorosłymi migrantami niesie ze sobą szereg wyzwań i jest trudna dla obu stron, ponieważ także często sami cudzoziemcy stawiają się w pozycji bezradnej istoty. Taka wyuczona bezradność (zob. Witkowski, 2005, s. 30) może stanowić poważną barierę w upodmiotowieniu się migrantów, niezależnie czy są to uchodźczy czy imigranci ekonomiczni. Proces stawania się świadomym i odpowiedzialnym członkiem społeczności lokalnej i całego społeczeństwa wymaga zarówno od migranta, jak i od osób z nim pracujących refleksyjności, uczenia się przez doświadczenie (Jarvis, 2006), wyciągania wniosków z własnych błędów, dialogu i otwartości na zmianę. Przed podobnymi wyzwaniami, jako osoba pracująca z osobami odmiennymi kulturowo, ubogimi i zmarginalizowanymi, stawała nie tylko Addams (Addams, 1910), ale także wielu innych działaczy środowiskowych ostatniego stulecia. Wspieranie emancypacji migrantów jest od kilku lat ważnym elementem pracy również wielu organizacji pozarządowych w Polsce. Aktywności podejmowane w ramach czy to warszawskiego Centrum Wielokulturowego, czy też działania wpisujące się w gdański Model Integracji Imigrantów (Fedes, Siciarek, Olech, 2016) u swoich podstaw mają właśnie dążenie do wzmacniania migrantów, którzy w założeniu mają samostanowić o sobie i podejmować decyzja dotyczące ich własnych dispor. W Gdańsku, aby wzmocnić oddziaływanie społeczności cudzoziemskiej, powołano Radę Imigrantów i Imigrantek (kadencja I w latach 2016-2018). Warszawskie Centrum Wielokulturowe z kolei kierowane jest przez wieloetniczny zarząd. Wiele innych organizacji w podobny sposób pracuje z migrantami i na ich rzecz ${ }^{8}$, traktując ich z szacunkiem i zrozumieniem oraz doceniając ich kompetencje i włączając jako wykonawców w swoje działania9. Niestety dzia-

${ }^{8}$ Wśród takich inicjatyw można znaleźć Fundację Ocalenie, Fundację Sintar, Muzułmańskie Centrum Kulturalno Oświatowe w Poznaniu, Fundacja dla Somalii, Ukraiński Dom w Warszawie, Fundacja Wolna Syria, Fundacja Kobiety Wędrowne.

${ }^{9}$ W wielu większych polskich miastach działają mentorzy kulturowi - czyli migranci, którzy przeszli już proces integracji i pomagają innym migrantom włączyć się w społeczności, w których żyją. 
łania te dotyczą niewielkiej liczby cudzoziemców - głównie liderów społeczności migranckich - osób, które osiągnęły sukces integracyjny. Zdarza się cały czas, że czasami taka aktywność ma charakter fasadowej integracji - wykorzystywana jest do budowania pozornego wrażenia integracji całej reprezentowanej przez migranta grupy (Pietrusińska, 2018). Często ich obecność w ciałach decyzyjnych ma wymiar działania pozornego lub wręcz braku uczestnictwa (Arnstein, 2012). Model rzeczywistego uczestnictwa i zaangażowania migrantów decydujących o losach lokalnej wspólnoty wydaje się w realiach współczesnej Polski daleki od ideałów progresywistów pokroju Addams.

Aby znaleźć odpowiedź na pytanie. dlaczego tak się dzieje, warto odnieść się do samego sposobu, w jaki migranci uczą się, jak być nowymi członkami społeczności, w których żyją. Opisane powyżej inicjatywy integracji cudzoziemców przeważnie opierają się na koncepcji lokalnej edukacji dorosłych - jedną z trzech koncepcji andragogicznych uczenia się w społecznościach lokalnych (Johnson, 2003, s. 16-17). Zgodnie z tym podejście edukacja jest łącznikiem miedzy tym, co prywatne, a tym, co publiczne w danej społeczności i najczęściej jest sumą zainteresowań oraz potrzeb mieszkańców lokalnych danego środowiska wspieraną i modelowaną przez lokalne (regionalne, miejskie, gminne, dzielnicowe) władze w oparciu o ich potrzeby. Inicjatywny wspomagające integrację migrantów zanurzone w tym podejściu są najchętniej popierane i finansowane.

W porównaniu do tradycji liberalnej, nastawionej na indywidualne efekty i rozwój osobisty, ta forma edukacji sprzyja budowaniu wspólnot i wspieraniu władz samorządowych w rozwiązywaniu problemów i zaspokajaniu potrzeb społecznych przy jednoczesnym uprawomocnianiu swojej władzy. Efekty społeczne tego nurtu edukacji dorosłych są zdecydowanie łatwiejsze do kontrolowania w porównaniu do nurtu radykalnego. Nurt radykalny opiera się bowiem na wzmacnianiu refleksyjności i krytycznego myślenia w celu demaskowania przemocy ze strony władzy, walczenia o swoje prawa, obrony przed wpływami kapitalizmu i biurokracji, czy wreszcie pełnego praktykowanie demokracji (m.in. poprzez organizowanie protestów, strajków, zgłaszanie petycji itp.) (Brookfield, 2005). Wydaje się więc nierzeczywiste, że jakakolwiek władza wspierałaby emancypację mogącą jej zagrozić. Edukacja w społecznościach lokalnych dąży raczej do zachowania statusu quo i koncyliacyjnego rozwiązywania problemów. Wspiera się więc lokalność i budowanie pomostowego kapitału społecznego wzmacniającego całą wspólnotę.

W przypadku działań integracyjnych przeważnie ten właśnie nurt mniej lub bardziej świadomie jest wybierany przez osoby działające na rzecz integracji i inkluzji. Faktem jest, że w odróżnieniu od XIX-wiecznej koncepcji Hull House, którego funkcjonowanie cechowało się oddolnym obywatelskim wysiłkiem, polskie działa- 
nia na rzecz migrantów silnie uzależnione są od zewnętrznych czynników politycznych, systemowych i środowiskowych. Działania Addams także powiązane były z tymi czynnikami, jednak podstawą jej koncepcji był zarówno pozytywistyczny charakter działań społeczników, jak i pewna niezależność finansowa od państwa (środki pozyskiwała z dobrowolnych składek i darowizn osób zainteresowanych jej inicjatywą oraz lokalnych dotacji). Współczesne działania na rzecz migrantów mają zazwyczaj odgórny i do pewnego stopnia zinstytucjonalizowany charakter.

Takie uzależnienie od czynników zewnętrznych przekłada się także wyraźnie na jakość prowadzonych działań. Wiele współczesnych inicjatyw w porównaniu do wieloletniej inicjatywy Hull House Addams jest ograniczone czasowo właśnie ze względu na zewnętrzne finansowanie. Przykładem może być prowadzony przez uchodźców z Czeczenii w Gdańsku Orunii dom, w którym organizowano różnego rodzaju warsztaty oraz spotkania dla lokalnej społeczności, mające na celu zbliżenie ze sobą sąsiadów z różnych kultur (Łupak, 2016). Ze względów finansowych inicjatywa ta przetrwała niecały rok. Z kolei inicjatywy podejmowane oddolnie przez zwykłych obywateli nie zgadzających się z polityką rządu - albo dość szybko przestawały funkcjonować, albo też zinstytucjonalizowały się, jak miało to miejsce w przypadku inicjatywy Chlebem i Solą czy też Refugee Welcome Polska ${ }^{10}$. Należy zatem stawiać sobie pytanie, dzięki czemu możliwy jest współcześnie ewolucyjnych charakter pracy z migrantami? Jak wpływać na uczenie się przez doświadczenie i refleksyjne udoskonalanie działań integracyjnych oraz funkcjonowania lokalnej wspólnoty wzmacniać, by ograniczyć jego tymczasowy charakter? Jak pomagać samym migrantom wrastać w tkankę społeczną poprzez proces akceptowania zmian, przechodzenia z traumy do akceptacji nowej rzeczywistości i tworzenie nowych planów życiowych - w tempie i czasie dla nich najbardziej odpowiednim?

Addams postulowała, aby działania integracyjne miały charakter lokalny i czerpały z zasobów środowiska lokalnego, a długofalowość takiej inicjatywy jest kluczem do sukcesu. U Addams przejawiało się to w jej stylu pracy poprzez rzeczywiste działania w miejscach, gdzie mieszkają migranci, zamieszkaniu razem z nimi i codziennej pracy ze wszystkimi mieszkańcami na rzecz danej społeczności. Współcześnie przykładami wykorzystania siły lokalności w procesie

${ }^{10}$ Na tym tle warto wyróżnić kilka inicjatyw, które nadal utrzymują swój nieformalny charakter Dom Otwarty (edukacja, zbiórki rzeczy, lobbying na rzecz uchodźców), Noise for Refugee (zbieranie środków poprzez organizowanie koncertów na rzecz migrantów), Łódź pomaga uchodźcom (zbiórki na rzecz uchodźców), Refugees Szczecin (szerzenie świadomości społecznej), Witajcie w Krakowie (zbiórki rzeczy, lobbying na rzecz uchodźców). Jednak i te inicjatywy mają raczej akcyjny charakter a udział samych migrantów w ich tworzeniu jest dość ograniczony. 
integracji cudzoziemców jest na przykład warszawskie Centrum Wielokulturowe, które ma jednocześnie status Miejsca Aktywności Lokalnej, czyli miejsca, „które oprócz swojej codziennej działalności [...], wspierają lokalne pomysły i działania społeczne mieszkańców. MAL-e sprzyjają realizowaniu pomysłów mieszkańców, nawiązywaniu sąsiedzkich relacji oraz aktywnemu spędzaniu czasu wolnego w najbliższym otoczeniu” (Włodarczyk, 2014, s. 1). Potencjał tego miejsca nie jest jednak do końca wykorzystany, ponieważ migranci korzystający z Centrum raczej rzadko mieszkają w jego najbliższym sąsiedztwie, przez co więź emocjonalna z miejscem, która zakorzenia tożsamość jednostki (Theiss, 2001), na której bazowała w swych działaniach ponad wiek temu Addams, jest zdecydowanie słabsza. Rzeczywista praca środowiskowa powinna rozwijać się współcześnie w ośrodkach dla uchodźców, ale także społecznościach, gdzie na prawdę żyją migranci, np. Wółka Kosowska w okolicach Warszawy, Podkowa Leśna, w gdańskiej Orunii, na Osiedlu za Żelazną Bramą w Warszawie.

\section{UCZENIE SIĘ DEMOKRACJI PRZEZ SPOŁECZNOŚCI LOKALNE: INSPIRACJE I TRANSGRESJE INICJATYW SETTLEMENTÓW}

Koncepcja settelmentów możne stanowić źródło inspiracji dla pedagogów społecznych, animatorów, pracowników socjalnych i innych osób na co dzień pracujących z migrantami. Tym co Addams udało się rozwinąć najpełniej była koncepcja pracy środowiskowej z cudzoziemcami opartej o ich upodmiotowienie, wspólnotowość i lokalność. Chociaż w Polsce praca środowiskowa ma długą i bogatą tradycję (Rymsza, 2012), to jej odbiorców do tej pory nie stanowili migranci. Współcześnie ważnym wyzwaniem nie jest tylko zintegrowanie cudzoziemców, ale rzeczywista integracja, definiowana jako „proces złożony, (który) oddziałuje zarówno na imigrantów, jak i społeczeństwo przyjmujące i w przeciwieństwie do asymilacji zakłada, że proces dostosowania się imigrantów i społeczeństwa przyjmującego ma charakter dwustronn”y (Plewko, 2010). Praca z całą społecznością, a nie tylko wybranymi jej członkami, może stanowić naszym zdaniem narzędzie dla długofalowej integracji i głębokiej akceptacji, ale także narzędzie przełamywania tak silnych obecnie stereotypów dotyczących „Innego”.

Wzmacnianie całych społeczności, nie tylko w oparciu o lokalną edukację dorosłych, ale czerpiącą też z innych andragogicznych inspiracji, jak: uczenie się transformatywne (Mezirow, 2003), uczenie się przez doświadczenie (Jarvis, 2006) czy edukacja radykalna (Brookfield, 2005), może stanowić wsparcie dla upodmiatawiania migrantów, o co Addams tak walczyła. Podejścia te mogą być 
też z powodzeniem stosowane w budowaniu wielokulturowych, solidarnych społeczności lokalnych opartych o demokratyczne zasady.

Znaczenie potencjału lokalności, które pojawiało się w myśli Addams, współcześnie ma szanse jeszcze mocniej wybrzmieć jako nieodzowny element działań inkluzyjnych i integracyjnych. Radykalna polityka rządu, kreowania samorządowych polityk migracyjnych, ale także fiasko scentralizowanych programów integracyjnych (Bieniecki, Kaźmierkiewicz, Matusz-Protasiewicz, 2013) stanowią szansę dla tworzenia nowych programów i działań zakorzenionych w zasobach lokalnych i wykorzystujących realny potencjał społeczności. Takie działania powoli zaczynają rozwijać się, głównie w polskich miastach (ze względu na osiedlanie się w nich migrantów). Brakuje im jednak często wcześniejszej diagnozy lokalnej i wykorzystania zasobów społeczności. Naszym zdaniem może to wynikać z niewystarczającej liczby animatorów i pracowników środowiskowych posiadających kompetencje międzykulturowe, działających w obszarze inkluzji i integracji migrantów pracuje na stałę w środowiskach lokalnych. Współczesna sytuacja w Polsce i Europie skraca niestety czas na prowadzenie procesów inkluzji i integracji. Rosnące antagonizmy i napięcia społeczne nie dają społecznościom czasu na poznanie się wzajemne i budowanie fundamentów pracy środowiskowej, jaka była możliwa w XIX wieku.

Nie należy jednak zapominać, że działania w społecznościach w zakresie inkluzji i integracji migrantów stanowią szansę dla nieformalnej i pozaformalnej edukacji obywatelskiej - nie tylko w kontekście przygotowywania cudzoziemców do roli przyszłych obywateli, ale także do podnoszenia zarówno kompetencji obywatelskich, jak i zaangażowania społecznego i politycznego wszystkich członków społeczności. Spotkanie z Innym, często marginalizowanym, w gorszym położeniu ekonomicznym, społecznym, politycznym, kulturowym może stanowić impuls do głębszej refleksji, nie tylko nad sobą samym (Levinas 2000), ale też nad stanem całego społeczeństwa i w konsekwencji podjęcia określonego rodzaju działań. Zaktywizowanie się wielu zwykłych Polaków, którzy w czasie tzw. kryzysu uchodźczego prowadzili zbiórki dla uchodźców, jeździli z zebranymi rzeczami i pieniędzmi do Serbii, Grecji, Chorwacji do obozów dla uchodźców czy prowadzili na miejscu zupełnie oddolne działania edukacyjne mające przygotować polskie społeczeństwo na przyjęcie uchodźców (uchodzcy.info), świadczyć może o potencjale drzemiącym w polskim społeczeństwie, który nie powinien zostać utracony. 


\section{ZAKOŃCZENIE}

Chociaż idea settlement powstałą w zupełnie innym kontekście historycznym, społecznym i politycznym wypracowany przez Addams paradygmat pracy z migrantami oparty na ich emancypacji, wspólnotowości i solidarności oraz lokalności wydaje się nadal aktualny i cenny. W Polsce dopiero od niedawna na większą skalę i z poparciem władz lokalnych prowadzi się działania rzeczywiście, a nie fasadowo, integrujące migrantów i członków społeczeństwa przyjmującego. Pojawiające się jednak inicjatywny opisane przez nas w tym artykule świadczą o przemianie myślenia o integracji. Zostało w nich ukazane, jak ważnym ogniwem integracji społecznej jest wzajemny stosunek ludzi do siebie. Bez osobistego spotkania narażamy się na stereotypowe, negatywne postawy ochronne. Dopiero czas i doświadczenie, które zdobywamy w trakcie osiedlania się w środowisku (ang. to settle), pozwala zrozumieć że status osiedleńców i/lub migrantów stanowi potencjał, który posiadamy wszyscy, ale także, że określenie settlement to nie tylko synonim tradycji programów społecznych o charakterze integracyjnym, ile proces refleksji każdego z nas nad własnym „osadzaniem się” w środowisku - uczeniem się jego reguł, norm i zasad, budowaniem relacji i więzi z innymi, akceptowaniem czyjejś inności.

\section{Bibliografia}

Adamczyk, A. (2017). Kryzys migracyjny w Europie a polska polityka imigracyjna. StudiaMigracyjne - PrzegladPolonijny, 163, s. 307-331.

Addams, J. (1902). Democracy and Social Ethics. New York: Macmillan.

Addams, J. (1910). Twenty Years at Hull-House with Autobiographical Notes. New York: Macmillan.

Addams, J. (1912). A New Conscience and an Ancient Evil. New York: Macmillan.

Ager, A., Stranger, A. (2004). Indicators of Integration: final report. Edinburg: Queen Margaret University College.

Arnstein, Sh. (2012). Drabina partycypacji. W: P. Sadura. J. Erbel (red.), Partycypacja. Przewodnik Krytyki Politycznej. Warszawa: Krytyka Polityczna.

Barbuto, D.M. (1999). American Settlement House and Progressive Social Reform. An Encyclopedia of the American Settlement Movement. Phoenix, Arizona: Oryx Press.

Bieniecki, M., Kaźmierkiewicz, P., Matusz-Protasiewicz, P. (2013). Ewaluacja i ocenan skuteczności działań prowadzonych w Polsce przy finansowym wsparciu Europejskiego Funduszu na rzecz Integracji Obywateli Państw Trzecich w latach 2007-2012. Gliwice: Instytut Studiów Migracyjnych.

Brookfield, S. (2005). The Power of Critical Theory for Adult Learning and Teaching.

New York: Two Penn Plaza. 
Bryan, M., McCree, M., Davis, A. (eds.). (1990). One Hundred Years at Hull-House. Bloomington: Indiana University Press.

Budyta-Budzińska, M. (2016). Polacy na Islandii. Rekonstrukcja przestrzeniobecności. Warszawa: PWN.

CBOS (2018). Stosunek Polaków i Czechów do przyjmowania uchodźców. Komunikat z badań Nr 87/2018. Pobrane z: https://www.cbos.pl/SPISKOM.POL/2018/K_087_18. PDF.

Chmielewski, W., Nackenoff, C., Fischer, M.. (2009). Jane Addams and the Practice of Democracy. Champaign, Ilinois: University of Illinois Press.

Deegan, M. (2002). Hull-House, and the University of Chicago: A New Conscience Against Ancient Evils. Westport, Conn.: Praeger.

Diouf, M., Średziński, P. (2012). Integracja przez kulturę i wzajemne poznanie. Warszawa: Fundacja „AfrykaInaczej”.

Elshtain, J.B. (2002). Jane Addams and the Dream of American Democracy. New York: Basic Books.

Fedas, A., Siciarek, M., Olech, P. (red.). (2016) Model Integracji Migrantów. Gdańsk: Urząd Miasta Gdańsk.

Firor Scott, A. (2004). Introduction, w: Addams J., My Friend Julia Lathrop. Chicago: Macmillan.

Fradin, J.B., Fradin, D.B. (2006). Jane Addams: champion of democracy. New York: Clarion Books.

Glowacki, P., Hendry, J. (2004). Hull-House. Charleston, S.C.: Arcadia.

Gmiterek-Zabłocka, L. (2018). Od 15 lat pomagajq cudzoziemcom w Polsce, w tym uchodźcom. A dziś? Muszq prosić o 3 tysiqce zł. Tok FM. Pobrane z: http://www. tokfm.pl/Tokfm/7,103454,23157327,od-15-lat-pomagaja-cudzoziemcom-w-polsce-w-tym-uchodzcom-a.html.

Hadzińska-Wyrobek, A. (2011). Wizerunek uchodźcy w polskiej prasie po 1990 r. oraz rola mediów w kształtowaniu stereotypu uciekiniera. Media, Kultura, Społeczeństwo, 1(6), s. 113-125.

Hall, D., Mikulska-Jolles, A. (2016). Uprzedzenia, strach czy niewiedza? Młodzi Polacy o powodach niechęci do przyjmowania uchodźców. Analizy, Raporty, Ekspertyzy, 1. Warszawa: Stowarzyszenie Interwencji Prawnej.

Jarvis, P. (2006). Towards a comprehensive theory of human learning. Londyn-Nowy Jork: Routledge.

Johnson, R. (2003). Adult Learning and Citizenship: Clearing the Ground. W: P. Coare, R. Johtson (red), Adult learning, citizenship and community learning. Oxford: NIACE.

Kishel, A.M. (2007). Jane Addams: a life of cooperation. Minneapolis, Minnesota: Lerner Publications Co.

Klaus, W., Ostaszewska-Żuk, E., Szczepanik, M. (2017). Fundusze Europejskie i ich rola we wspieraniu integracji cudzoziemców w Polsce. Warszawa: Stowarzyszenie Interwencji Prawnej.

Knight, LW. (2010). Jane Adams, Spirit in Action. New York: W.W. Norton \& Company, Inc. 
Knight L.W. (2005). Citizen: Jane Addams and the struggle for Democracy. Chicago: The University of Chicago Press.

Kledzik, E., Praczyk, M. (red.). (2016). Edukacja. Migracja. Edukacja międzykulturowa w kontekście kryzysu migracyjnego z perspektywy krajów V4. Pobrane z: edukacjamigracja.amu.edu.pl/download.php.

Komisja Europejska (2018). Local integration of migrants. Pobrane z: https://ec.europa.eu/ regional_policy/sources/docgener/factsheet/oecd_local_integration_migrants_en.pdf.

Kropiński, M.., Hasen, K. (2016). Jakie skojarzenia ze słowem „uchodźca” majq Polacy? Warszawa: Centrum Badań nad Uprzedzeniami.

Kubicki, P., Pawlak, M., Mica, A., Horolets, A. (2017). Wyjście z cienia: Polityka uchodźcza w sytuacji kryzysu. Polityka Społeczna, 9(522), s. 22-28.

Leszkowicz-Baczyński, J. (2017). Koncepcja lęku społecznego jako składnik analizy uwarunkowań postrzegania imigrantów przez Polaków w świetle kryzysu migracyjnego w Europie. W: A. Adamczyk, A. Sakson, C. Trosiak (red.), Między tolerancjq a niechęciq. Polityka współczesnych państw europejskich wobec migrantów i mniejszości. Poznań: Wydawnictwo Naukowe WNPiD UAM.

Lévinas, E. (2000). Inaczej niż być lub ponad istotq. Warszawa: Fundacja Aletheia.

Linn, J.W., Scott, A.F. (2000). Jane Addams: a biography. Urbana, University of Illinois Press.

Łazor, J. (2016). Polska polityka imigracyjna wobec cudzoziemców, 1918-2012. W: K. Górak-Sosnowska, J. Łazor (red.), Polityka migracyjna: historia i współczesne wyzwania. Warszawa: Oficyna Wydawnicza SGH, s. 103-120.

Łodziński, S., Szornet, M. (2016). Niepolityczna polityka? Kształtowanie się polityki migracyjnej w Polsce w latach 1989-2016. CMR Working Papers, 90/148, Warszawa: Ośrodek Badań nad Migracjami.

Łupak, D. (2016), Mała Czeczenia na gdańskiej Oruni. Kilka rodzin uczy się wspólnie życia w Polsce. Gdańska.pl. Pobrane z: https://www.gdansk.pl/wiadomosci/Mala-Czeczenia-na-gdanskiej-Oruni-Kilka-rodzin-uczy-sie-wspolnie-zycia-w-Polsce,a,65702.

Matyja, R., Siewierska-Chmaj, A., Pędziwiatr, K. (2015). Polska polityka migracyjna. W poszukiwaniu nowego modelu. Warszawa-Rzeszów: WUW.

Mezirow, J., (2003). Transformative Learning as Discourse. Journal of Transformative Education 1(1), 58-63. DOI: 10.1177/1541344603252172 Sage.

Naumiuk, A. (2016). Jane Addams i jej koncepcja pracy w środowisku społecznym. Pedagogika Społeczna, 3(61), s. 37-54.

Obwieszczenie Marszałka Sejmu Rzeczypospolitej Polskiej z dnia 10 maja 2018 r. w sprawie ogłoszenia jednolitego tekstu ustawy o zalegalizowaniu pobytu niektórych cudzoziemców na terytorium Rzeczypospolitej Polskiej oraz o zmianie ustawy o udzielaniu cudzoziemcom ochrony na terytorium Rzeczypospolitej Polskiej i ustawy o cudzoziemcach. Dz.U. 2018, poz. 1156.

Opdycke, S. (2012). Jane Addams and Her Vision for America. Upper Saddle River, New York: Pearson Education.

Pasamonik B. (2017). Malowanie strasznego diabła - metamorfoza obrazu uchodźcy w Polsce. W: B. Pasamonik, U. Markowska-Manista (red.), Kryzys migracyjny. Per- 
spektywa społeczno-kulturowa.Tom 1. Warszawa: Wydawnictwo Akademii Pedagogiki Specjalnej.

Pietrusińska, M. (2018). Inny - ja czy Obcy - potrzebujący. Wizerunki uchodźcy w prouchodźczych działaniach edukacyjnych. Czas Kultury 3, s. 150-158.

Plewko, J. (2010). Warunki integracji imigrantów ze społeczeństwem przyjmującym w wybranych krajach Unii Europejskiej. Rocznik Nauk Społecznych, 2(38), s. 157-180.

Rajca, L. (2015). Integracja imigrantów w Polsce w dobie kryzysu migracyjno-uchodźczego. Chorzowskie Studia Polityczne, 10, s. 183-202.

Rymsza, M. (2012). W stronę pracy środowiskowej i nowych ról zawodowych pracowników socjalnych. W: M. Rymsza (red), Pracownicy socjalni i praca socjalna w Polsce. Między służbq społecznq a urzędem (s. 202-226). Warszawa: Instytut Spraw Publicznych.

Sitko, A. (2016). Rola społeczności lokalnych w integracji uchodźców w Polsce. Warszawa: Instytut Spraw Publicznych.

Theiss, W. (2001). Mała ojczyzna: perspektywa edukacyjno-utylitarna. W: W. Theiss (red.), Mała ojczyzna: kultura, edukacja, rozwój lokalny. Warszawa: Wydawnictwo Akademickie Żak.

Ustawa z dn. 25 czerwca 1997 o cudzoziemcach. Dz.U. 1997, nr 114, poz. 739.

Ustawa z dnia 12 grudnia 2013 r. o cudzoziemcach. Dz.U. 2013, poz. 1650.

Wielogłos. Integracja migrantów i uchodźców w polskich gminach (2016). Toruń: Fundacja Emic.

Witkowski, L. (2005), O paradoksach marginalizacji. Dwadzieścia dwa przejawy zmiany statusu marginesu w społeczeństwie i w naukach społecznych. W: K. Marzec-Holka (przy współpracy H. Guzy-Steinke, A. Rutkowskiej) (red.), Marginalizacja w problematyce pedagogiki społecznej i praktyce pracy socjalnej. Bydgoszcz: Wydawnictwo Uniwersytetu Kazimierza Wielkiego.

Włodarczyk, Z. (2014). Warszawskie Miejsca Aktywności Lokalnej. Pobrane z: http:// inicjatywa.um.warszawa.pl/mal.

Zielińska, M. (2013). Migration and Adult Education: time, place and power - Polish migrants in Reykjavik, Iceland. Power and Education, 5(2), s. 120-136.

Ziętek, A. (2017). Sekurytyzacja migracji w bezpieczeństwie kulturowym. OL PAN, 12/3, s. 23-42.

\section{Netografia}

https://socialwelfare.library.vcu.edu/settlement-houses/hull-house/.

http://www.democraticunderground.com/discuss/duboard.php?az=view_all\&addres$\mathrm{s}=132 \times 6932135$.

http://www.famous-people.info/21/Jane-Addams.html.

http://www.janeaddamsschool.org/jas/nonflash/blog.html.

http://www.britannica.com/EBchecked/topic/275272/Hull-House.

https://www.britannica.com/place/Chicago/History.

https://www.hullhousemuseum.org/.

http://www.encyclopedia.chicagohistory.org/pages/615.html.

http://uchodzcy.info.

http://migracje.gov.pl. 